\title{
Development of a Renewable Energy Based DC Excitation System in a Micro Hydro Power Plant
}

\author{
Mahmut Temel Ozdemir ${ }^{1}$, Gökay Bayrak ${ }^{2}$, Muhsin Tunay Gencoglu ${ }^{1}$ and Mehmet Cebeci ${ }^{1}$ \\ 1. Electrical and Electronics Engineering Department, Faculty of Engineering, Firat University, Elazig 23100, Turkey \\ 2. Electrical and Electronics Engineering Department, Faculty of Natural Sciences, Architecture and Engineering, Bursa Technical \\ University, Bursa 16190, Turkey
}

Received: November 03, 2015 / Accepted: November 27, 2015 / Published: January 31, 2016.

\begin{abstract}
MHPPs (micro hydro power plants) have become prominent in hydropower plants as a solution to provide the energy demands of the grid. In this study, a new hybrid renewable energy based DC excitation system for synchronous generator in the developed MHPP system is introduced. Proposed hybrid DC excitation system consists of solar \& hydrogen energy based power generating systems. Hybrid renewable energy based system is used for the excitation of the synchronous generator in the MHPP test system. The renewables are used as a secondary energy source to provide the excitation current to a synchronous generator that generates energy in MHPP. A PV (photovoltaic) array is used as the main source of excitation, and a FC (fuel cell) stack is used for DC excitation in the lack of sunshine. In the experimental setup, an electrical control card is developed, and a microcontroller is used to perform the proposed excitation system. All experimental results obtained from $5 \mathrm{~kW}$ rated power MHHP test system. Experimental results show that, the proposed method provides the continuous excitation current, and the operation of the synchronous generator is uninterrupted. The proposed method is also practical and easily implemented for MHPP systems.
\end{abstract}

Key words: Micro hydro power plant, excitation system photovoltaic system, fuel cell.

\section{Introduction}

Nowadays, continuously growing electrical energy market in the world is directed to alternative energy sources for investigating instead of fossil fuels. One of these most exploited renewable energy sources is called as hydropower. Therefore, it is important to provide maximum benefit from this potential. Large hydro-electrical power plants have very serious investment cost. Also, construction of these plants keeps on long years, and their dams may have negative effects on climate, environment and historical works of art. All of these reasons are forced to build mini and micro hydro-electrical power plants, particularly in countries.

Produced and consumed electrical power is

Corresponding author: Gökay Bayrak, assist. professor, research fields: grid-connected PV systems, islanding detection and fuel cell system. considered as the development level of a country. The developing countries have to improve their energy production to increase their development speed, and they can also get rid of foreign dependency.

The amount of fossil fuels keeping dropping, their harmful results for environments and also the continuous increment of energy demand makes renewable energy sources come into prominence. The hydroelectric power plants that are the one of the renewable energy sources meet twenty percent of the need of electrical energy in the world.

MHPPs (micro hydro power plants) are built as a river power plant, so they do not have a reservoir. A water level adjustment system is used instead of the reservoir where the penstock connected to the river. Powers of MHPPs change between $5 \mathrm{~kW}$ to $100 \mathrm{~kW}$, and there is no restriction about these limits. Also, there is a restriction about pico-hydroelectric power plants that are defined as the MHPPs under $5 \mathrm{~kW}$ [1]. The 
fundamentals of the MHPPs similar to significant and micro hydroelectric power plants, but each country may use different classifications about the subject.

Many different excitation methods have been put forward recently. IEEE has decided to prepare a standard about the excitation buildings of synchronous generators, and these have been classified as three DC-based excitations, seven AC-based excitations and three static-based excitations $[2,3]$.

Nowadays, PV and FC (fuel cell) system technologies have been improving, so renewable energy sources also increase the efficiency of small hydroelectric power plants. There have been a lot of researches, including automatic control of voltage and speed of energy transformation in synchronous generators [4-6]. The behavior of the alternators feeding the electrical system has a serious effect on the stability of power system in a fault situation [7, 8]. Steady state operation of alternators so most important subject to provide the power system stabilization, especially sudden load changes and faults $[9,10]$.

Ozturk [11] performed an experimental study of the turbine-generator system, and he used a synchronous generator and a DC motor instead of a turbine. Reliability analysis of hybrid PV generators and small hydropower plants are researched in Ref. [12]. In this study, an alternative method is proposed to generate power in remote regions instead of the conventional diesel generators by using PV generators with an alternator as a hybrid system. Adding a small loading pool to the hydropower plant has been increased the reliability of the system according to PV cell systems operating individually. The researchers in this paper also researched the effects of a battery system that added to the system. Operation and performance of a PV generator and a hydroelectric plant hybrid system are also studied in Ref. [13]. There have been also many studies about PV generators and hybrid systems for developing the performance of these systems and connecting them to the grid [14-16].

Today, the batteries have been used as the main excitation source in MHPPs [17-19], even they have many disadvantages to other excitation methods. The batteries have been charged in continuous operation. The charging condition has been obtained with a rectifier which using generated AC power [20-22].

\section{The Motivation of the Study}

A comparison of the current excitation methods is shown in Table $1[23,24]$. Table 1 also indicates the differences of the proposed excitation method.

The goal of this study is using two different type renewable energy sources for excitation of synchronous generator and developing a structure of the excitation current control. In the proposed method, there is not a battery system for the excitation, and the excitation also depends on a hybrid renewable energy system that consists of a PV system and a fuel cell system. These renewable energy sources supply the DC voltage directly, so the proposed system does not require a conversion system. The proposed method provides an easy and sustainable control of voltage reactive power. The proposed method is also independent of the weather conditions.

In the study, a developed MHPP test system in the laboratory is presented and new hybrid renewable energy based DC excitation system for synchronous generator in this developed MHPP system is introduced. The proposed hybrid DC excitation system consists of a PV generator and an FC stack. The hybrid system is used for the excitation of the synchronous generator in developing MHPP test system, and it is used as a secondary energy source to provide the excitation current of the synchronous generator. Renewables generate DC power to supply the required excitation current, so this condition increases the overall efficiency of the system. The PV generator is used as the main source of excitation, and a FC stack is used for DC excitation in the lack of sunshine. In the experimental setup, an electrical control card is developed, and a microcontroller is used to perform the proposed excitation system. 
Table 1 A comparison of the current excitation methods.

\begin{tabular}{|c|c|c|c|}
\hline $\begin{array}{l}\text { Excitation } \\
\text { source }\end{array}$ & $\begin{array}{l}\text { Effect on the voltage } \\
\text { control }\end{array}$ & Technical disadvantages and environmental effects & Cost \\
\hline Batteries & $\begin{array}{l}\text { Easy control of voltage } \\
\text { (reactive power) }\end{array}$ & $\begin{array}{l}\text { - Requiring continuous charge support. } \\
\text { - Battery lifetime is a restriction. } \\
\text { - Battery life cycle is an important problem. }\end{array}$ & Low \\
\hline $\begin{array}{l}\text { AC-DC } \\
\text { rectifiers }\end{array}$ & $\begin{array}{l}\text { Easy implementation. } \\
\text { Difficult control of voltage } \\
\text { (reactive power) }\end{array}$ & $\begin{array}{l}\text { - The nonlinearity of the system increases depending on the generator load, and } \\
\text { this condition makes frequency-voltage control difficult. } \\
\text { - The quality of the energy decreases. } \\
\text { - There is no environmental effect. }\end{array}$ & Lowest \\
\hline Solar energy & $\begin{array}{l}\text { The control of voltage is } \\
\text { easy in a condition of } \\
\text { sufficient solar irradiation. }\end{array}$ & $\begin{array}{l}\text { - The solar energy depends on the solar irradiation and the module temperature, } \\
\text { so an extra power supply is necessary for the sustainable excitation. } \\
\text { - It is a renewable energy source that it could be easily obtained. }\end{array}$ & Medium \\
\hline Wind energy & $\begin{array}{l}\text { The control of voltage is } \\
\text { easy in a condition of } \\
\text { sufficient wind speed. }\end{array}$ & $\begin{array}{l}\text { - The wind energy depends on the wind speed, so an extra power supply is } \\
\text { necessary for the sustainable excitation. } \\
\text { - It is a renewable energy source, so it could be easily obtained. }\end{array}$ & Medium \\
\hline DC generator & $\begin{array}{l}\text { There are many physical } \\
\text { installing difficulties. } \\
\text { Difficult control of } \\
\text { voltage. }\end{array}$ & $\begin{array}{l}\text { - The driving of the generator is obtained with a hydro turbine, so the } \\
\text { nonlinearity of the system increases depending on the generator load, and this } \\
\text { condition makes frequency-voltage control difficult. } \\
\text { - The quality of the energy decreases. } \\
\text { - The brush and collector are other problems in DC generators. } \\
\text { - There is no environmental effect. }\end{array}$ & Medium \\
\hline $\begin{array}{l}\text { Proposed } \\
\text { renewable } \\
\text { energy based } \\
\text { DC excitation } \\
\text { system }\end{array}$ & $\begin{array}{l}\text { Easy and sustainable } \\
\text { control of voltage } \\
\text { (reactive power). }\end{array}$ & $\begin{array}{l}\text { - A hybrid (PV and fuel cell) system is used for the excitation of the } \\
\text { synchronous generator. } \\
\text { - The proposed method is independent of the weather conditions. } \\
\text { - Two different renewable energy sources are used for excitation of } \\
\text { synchronous generator. } \\
\text { - In this control system, a new structure has been used differently from the } \\
\text { classical hybrid systems. Synchronous generator excitation losses have been } \\
\text { obtained from PV/fuel cell modules. } \\
\text { - Plenty of sunshine has been increased the electrical output of the generator. } \\
\text { - The renewables are used as a secondary energy source to provide the } \\
\text { excitation current to a synchronous generator that generates energy in MHPP. } \\
\text { - There is no environmental effect. }\end{array}$ & High \\
\hline
\end{tabular}

\section{Developed MHPP in the Laboratory}

In this section, the general structure and the main parts of the developed MHPP test plant in the laboratory are presented. The developed MHPP system is constituted in the laboratory. The general structure of developed micro hydropower test plant in the laboratory is shown in Fig. 1. MHPP system consists of a reservoir tank, an induction motor for pumping the water to the reservoir, a motor driver and a Pelton turbine coupled with a $5 \mathrm{~kW}$ synchronous generator. A linear actuator is used for controlling the Pelton turbine to adjust the generator speed, a synchroscope device for connecting the MHPP system to the electrical grid, a PLC (programmable logic controller) unit for controlling the whole system, an operator panel and a computer for monitoring and controlling the system.
The proposed DC excitation system consists of a PV generator and a fuel cell stack. The experimental setup in the laboratory is also shown in Fig. 2.

MHPP system that has different excitation sources is shown in Fig. 1. In this structure, different excitation sources are included (a PV generator and fuel cell stack) for the voltage control of the MHPP system, and reactive power control of the system is performed with the voltage control. Fig. 3 also indicates the block diagram of the developed MHPP system that consists of hydraulic, electro-mechanic and the control systems.

In Fig. 4, the main electro-mechanical components of a closed circulation system prototype are shown. The water power obtained from the pressure stabilizer is used for the input of the turbine as mechanical power, and then wasted water is pumped back into the water tank. A closed water circulation loop is achieved 


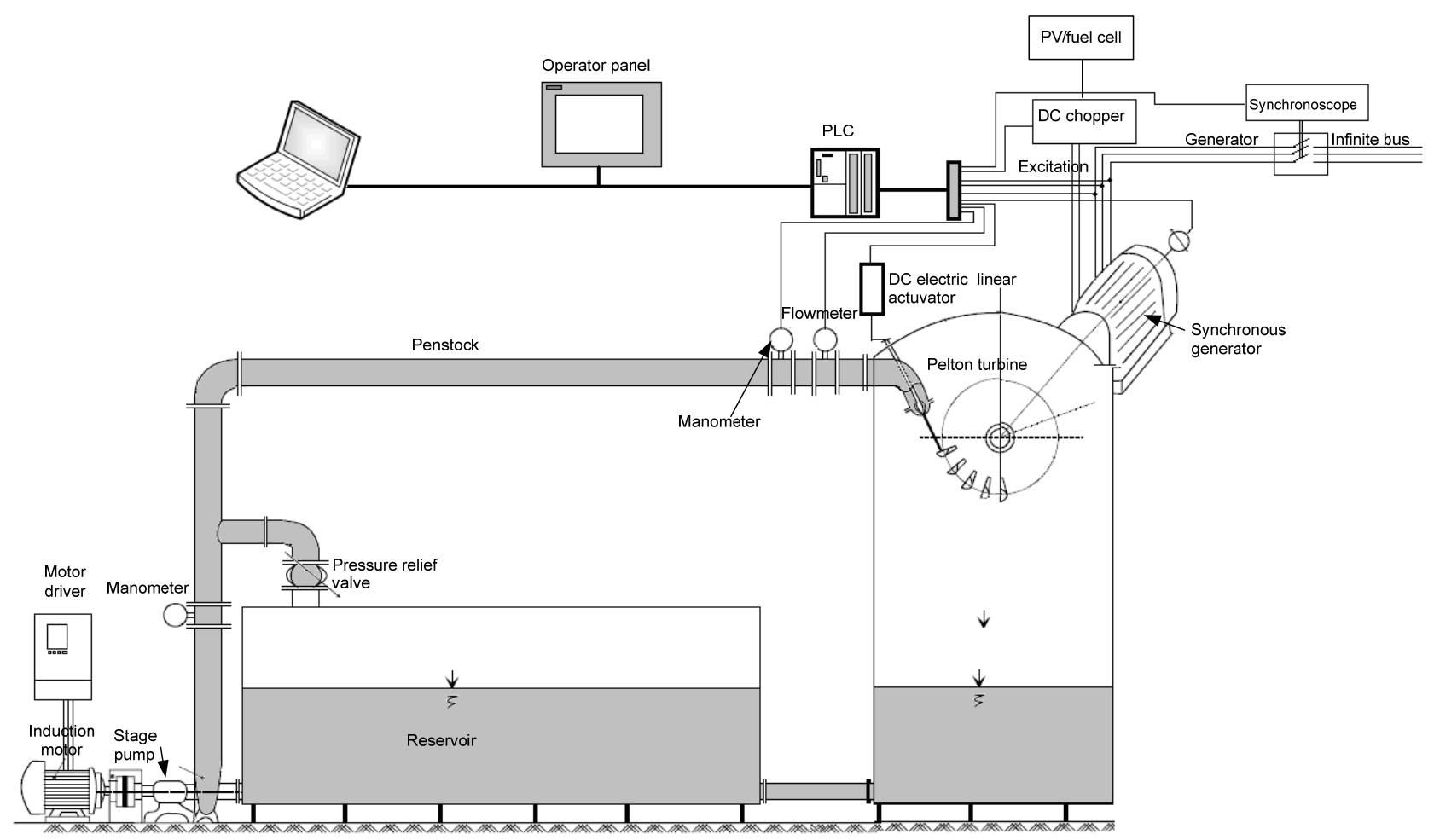

Fig. 1 Developed micro hydropower test plant in the laboratory.

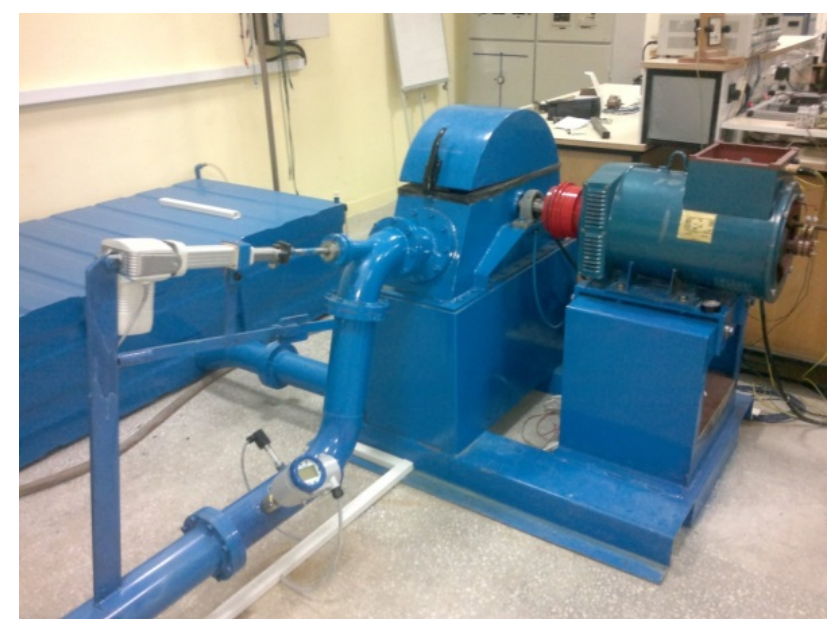

Fig. 2 Experimental setup.

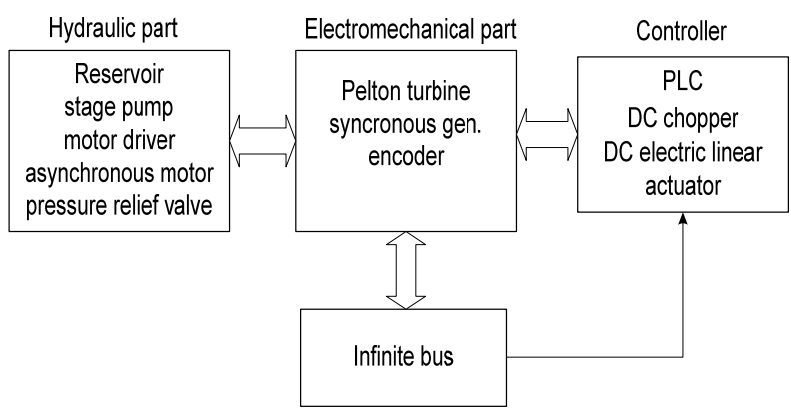

Fig. 3 The block diagram of developed test MHPP system.

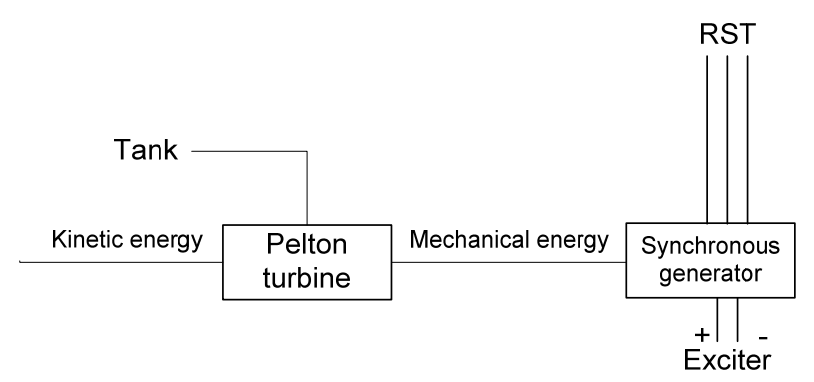

Fig. 4 Turbine-generator part of prototype MHPP.

thanks to this way, and the synchronous generator is excited by using this mechanic energy.

The rotating speed of a synchronous generator is proportional to the frequency of the output voltage, so the generator frequency can be controlled by controlling the flow rate. In a hydraulic power system, pressure-controlled systems are used for controlling the flow rate. In the proposed system, a linear activator is used as the solution. It moves linearly due to capable of managing easily, and its power consumption is less according to the hydraulic power plant. Applied linear activator that has a needle controls the flow rate of the system. The difference amount of the water by changing 
the rotating speed is provided by the movement of the needle.

The generator frequency is calculated by using two different methods in developed experimental system. One of them is using an encoder that sends signals to used PLC unit, and the other one is the developed micro-controller based synchronization circuit that calculates the frequency by counting the zero passing of the voltage.

The grid frequency is $50 \mathrm{~Hz}$, and the generator provides the synchronization being connected in parallel to the grid. The pole type and the pole number of a synchronous generator have emerged according to this knowledge. Because of this, round-cylindrical rotor synchronous generator that has some double-pole 3 (6-pole machine) is selected at high-speed in the proposed system.

There are two different types of excitation systems in the generator that can be implemented with different control strategies. These are rotating diodes and the ring system. This structure is given in Fig. 5.

\section{Proposed Renewable Energy Based DC Excitation System}

In the study, a new hybrid renewable energy based
DC excitation system for the synchronous generator is presented. The synchronous generator has two different excitation sources, and the general schematic of the proposed excitation system is shown in Fig. 5. The generator is suitable for AC excitation system and the static excitation system. Static excitation control is the important part of this study. Proposed hybrid DC excitation system consists of a PV power generator, and it is shown in Fig. 6. The FC stack is also shown in Fig. 7.

Hybrid renewable energy based system is used for the excitation of the synchronous generator in developing MHPP test system, and it is used as a secondary energy source to provide the excitation current to the synchronous generator. The solar energy is the primary energy source of excitation, and if there is not enough power from $\mathrm{PV}$ panels, FC stack is operated for DC excitation. An electrical control card was developed for this aim, and a PIC (peripheral interface controller) 16F877 microcontroller was used to control the proposed excitation system.

A voltage controller is used to operate the system in stable. The structure of the excitation system is shown in Fig. 5, is transformed to the proposed structure shown in Fig. 8 to provide the stability.

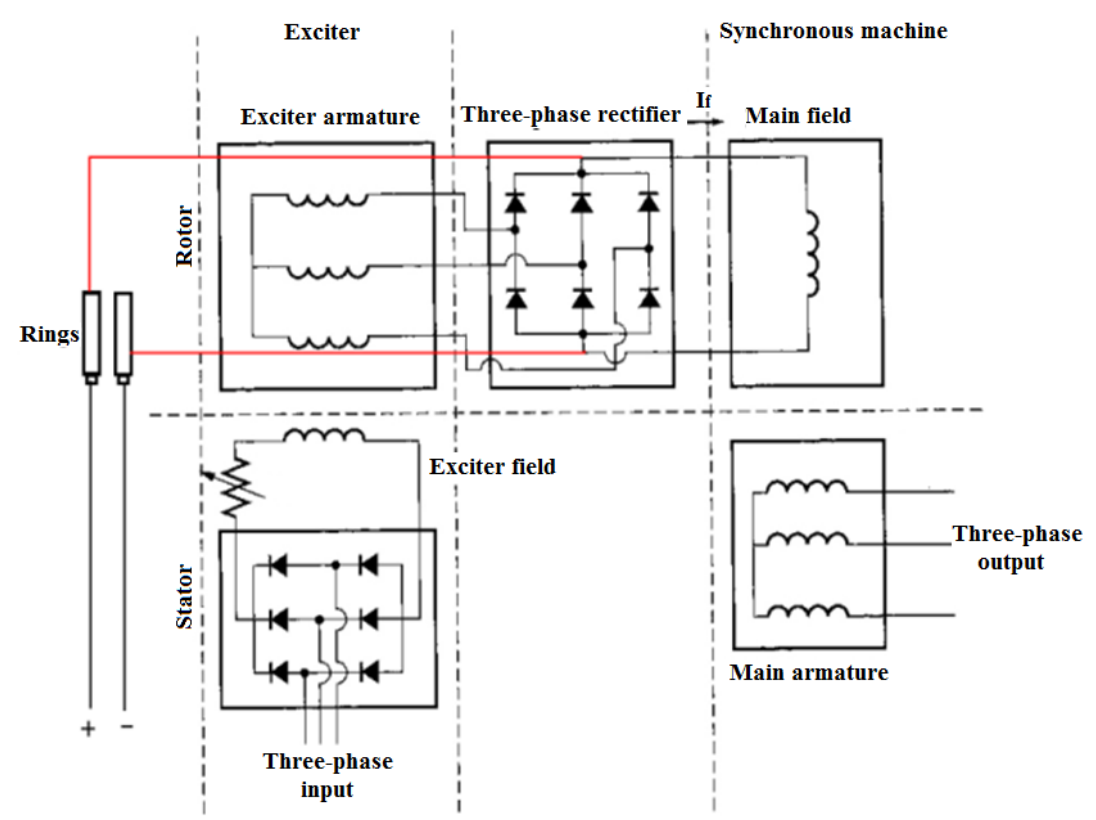

Fig. 5 Synchronous generator with two different excitations. 


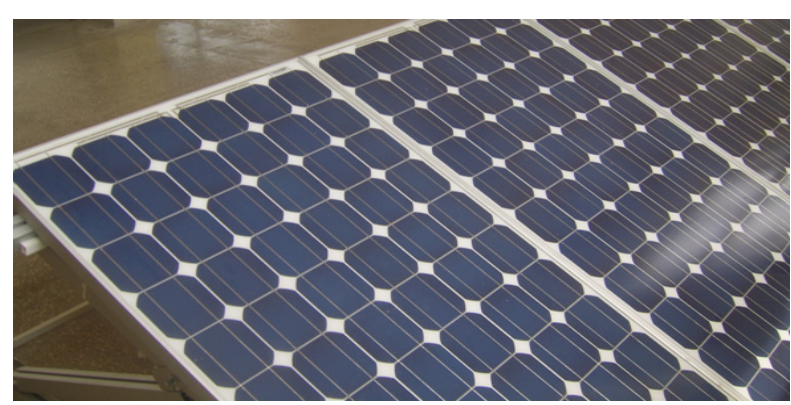

Fig. 6 PV array for proposed excitation system.

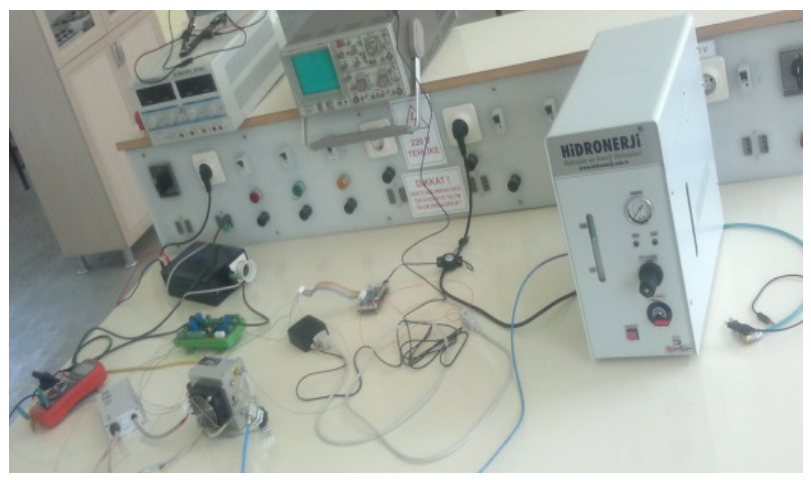

Fig. 7 Fuel cell stack for proposed excitation system.

The outputs of the DC excitation supplies are shown in Fig. 9, and they are used for the input of developed DC chopper circuit. DC chopper circuit is used for controlling the excitation current, and output of the DC chopper circuit is controlled with according to the duty cycle of PWM (pulse-width modulation) signals generated from the PLC. The developed DC chopper circuit for the excitation of the system is also shown in Fig. 9.

The technical specifications of the PV panels used in the developed MHPP system are shown in Table 2. The technical specifications of the used FC stack in developed MHPP system is also shown in Table 3.

An electrical control card was developed to make a suitable selection of the proper energy, and a PIC 16F877 microcontroller was used to control the proposed excitation system. The flow diagram of the excitation source selection for the developed MHPP

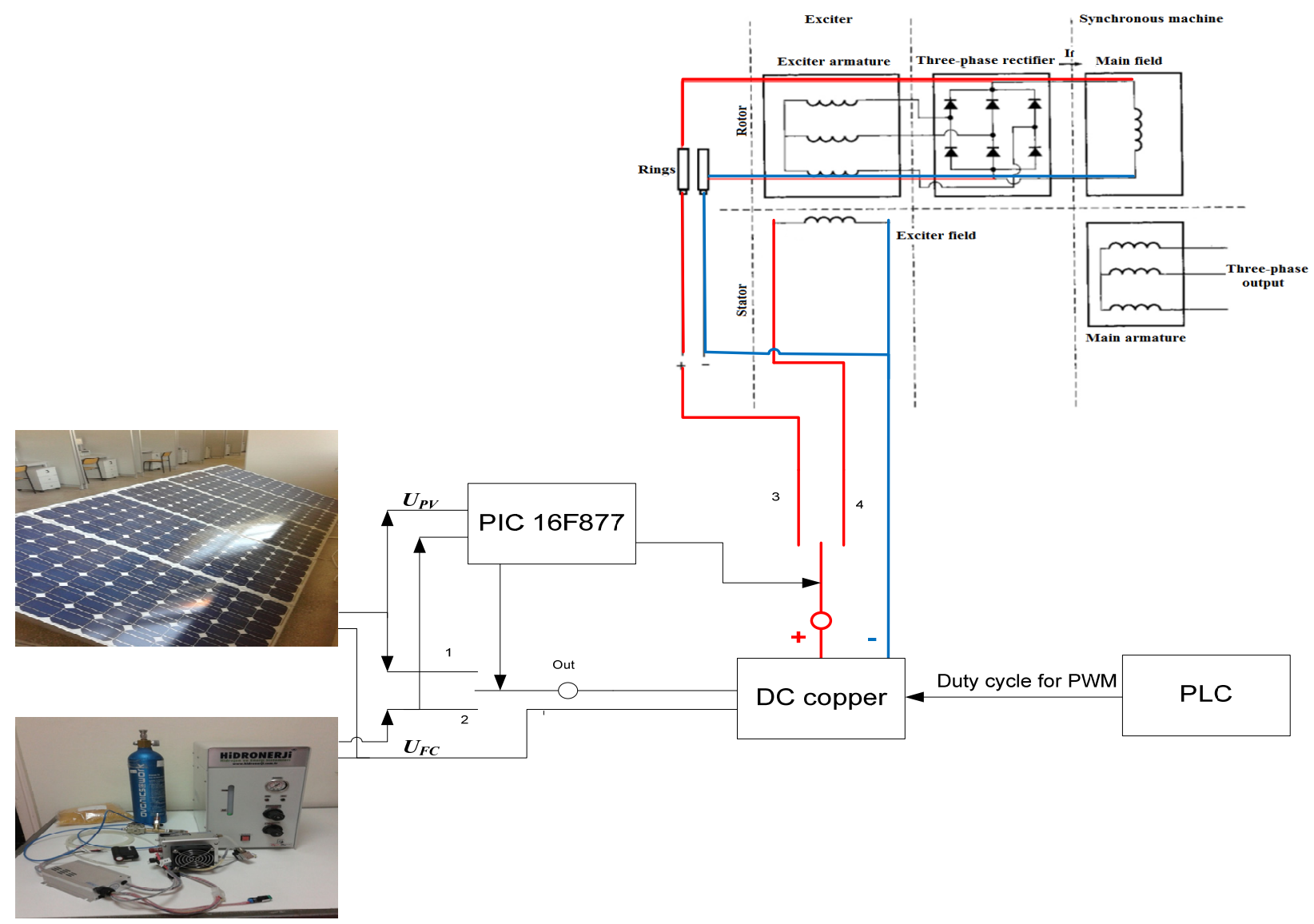

Fig. 8 The proposed excitation structure of MHPP system. 


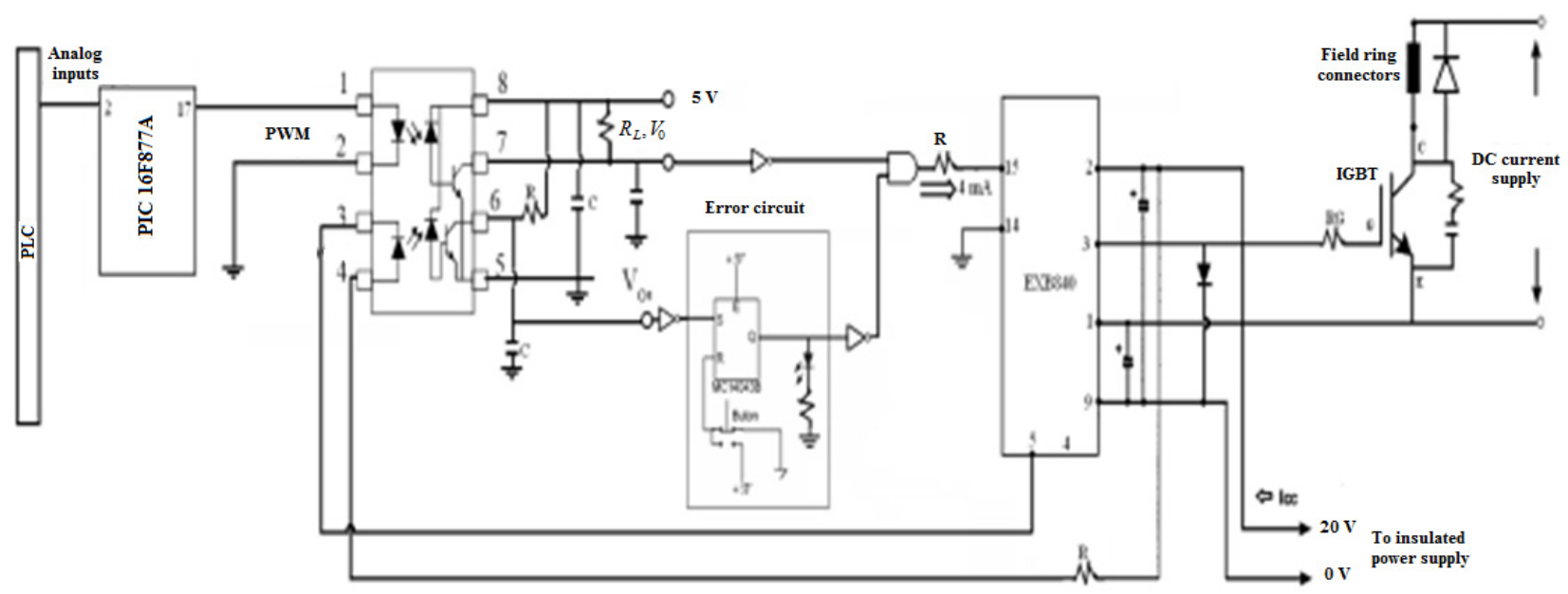

Fig. 9 Developed DC chopper circuit for the excitation.

Table 2 Specifications of PV cells.

\begin{tabular}{lllll}
\hline$U_{s y s}$ & $U_{m p p}$ & $I_{m p p}$ & $U_{O C}$ & $I_{S C}$ \\
\hline $225 \mathrm{~V}$ & $35.2 \mathrm{~V}$ & $4.4 \mathrm{~A}$ & $43.3 \mathrm{~V}$ & $4.98 \mathrm{~A}$ \\
\hline
\end{tabular}

Table 3 Specifications of fuel cell.

\begin{tabular}{llllll}
\hline Type of fuel cell & No. of cells & Rated power & Performance & $\mathrm{H}_{2}$ supply valve voltage & Reactants \\
\hline $\begin{array}{l}\text { PEM (proton } \\
\text { exchange } \\
\text { membrane) }\end{array}$ & 24 & $100 \mathrm{~W}$ & $14.4 \mathrm{~V} @ 7.2 \mathrm{~A}$ & $12 \mathrm{~V}$ & Hydrogen and air \\
\hline
\end{tabular}

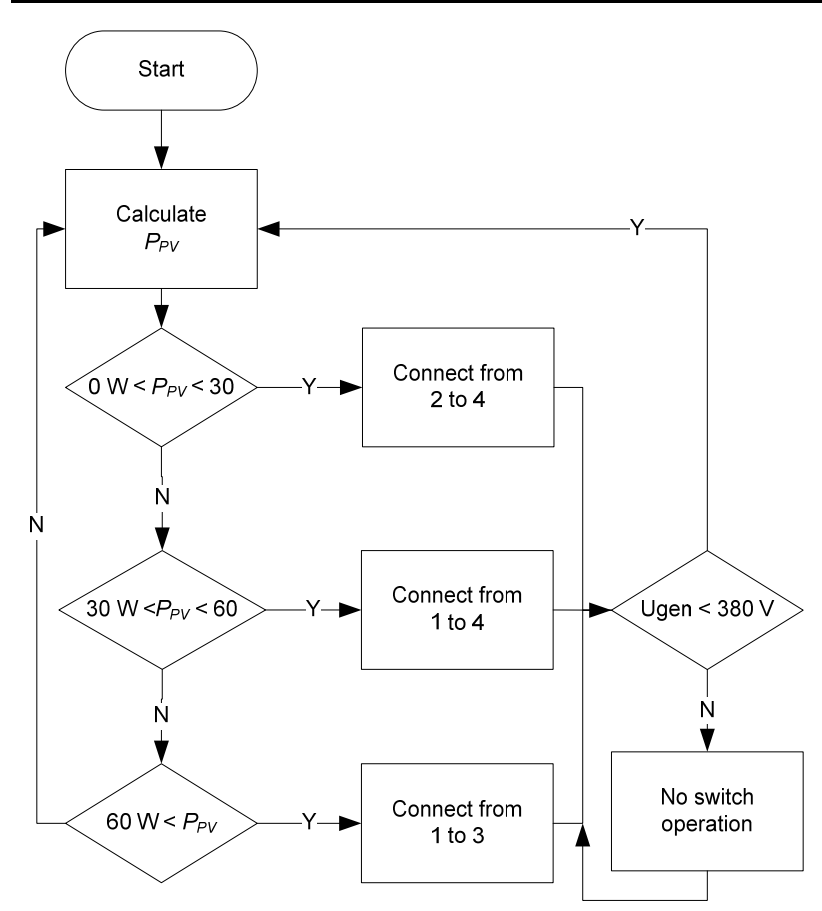

Fig. 10 Flow diagram of the excitation source switching.

system is shown in Fig. 10. The excitation source is selected according to the power of the PV generator. The power of PV generator depends on the climatic conditions, so the control card selects the proper DC excitation source for the MHPP system related to the generated power change by the climatic conditions.

\section{Results and Discussion}

The proposed excitation system that provides DC voltage from $\mathrm{PV} /$ fuel cell hybrid source is shown in Fig. 11. The PV power curves are shown in Fig. 11 was obtained from a pyranometer measures the solar irradiation and module temperature of the solar panels during a measurement data of $24 \mathrm{~h}$ in the Elazig province in Turkey. The switching conditions of the excitation of synchronous generator and the threshold values are also given below:

- If $P_{P V}<30 \mathrm{~W}$, connect from 2 to 4 and the excitation is supported by fuel cell (insufficient solar radiation);

- If $30 \mathrm{~W}<P_{P V}<60 \mathrm{~W}$, connect from 1 to 4 and the excitation is supported by $\mathrm{PV}$ generator;

- If $P_{P V}>60 \mathrm{~W}$ connect from 1 to 3 and the excitation is supported by $\mathrm{PV}$ generator. 


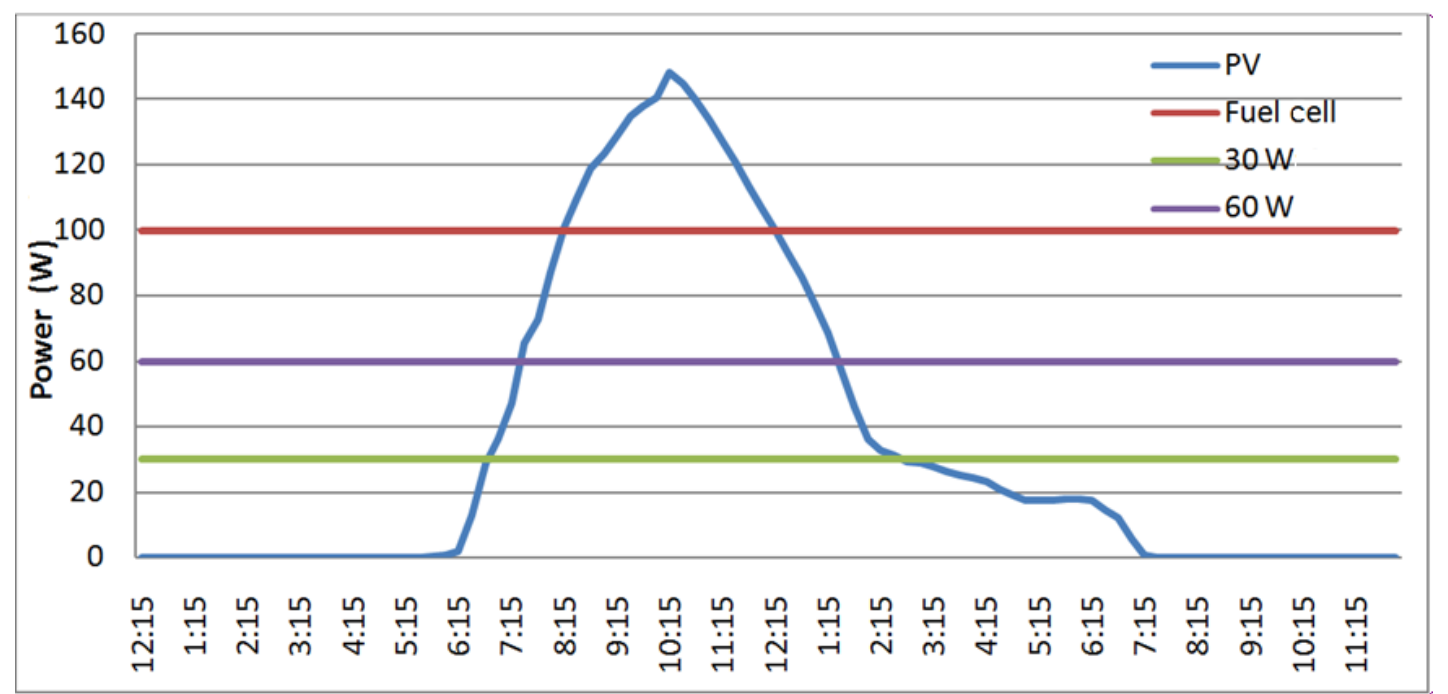

Fig. 11 PV and FC powers and switching threshold values.

This control structure was provided by the logic operation of excitation current. Thus, when PV supported energy is adequate, then PV system is used for excitation. When the power of fuel cell system is not enough, this time synchronous generator excitation power is provided by the PV system. In this operation, synchronous generator will continue to produce the desired manner. This process is run because of power mismatch between PV and FC system shown in Fig. 11, and this structure forces generated power can be made and used in PV step by step.

The proposed excitation system is used for the excitation of the synchronous generator. The screen shots of the PID (proportional, integral, derivative) controller obtained from the PLC are shown in Figs. 12 and 13. In these figures, the percentage of the $100 \%$ frequency equals to the $100 \mathrm{~Hz}$, and the percentage of the $84 \%$ voltage equals to the $380 \mathrm{~V}$. The power change of PV system for investigating the behavior of the proposed excitation system was achieved by making partial shading to the PV panels. Increasing and decreasing the source voltage is observed causing the little ripples in Fig. 12, and Fig. 13 and these ripples occur with the effect of the PWM. Despite the change of the source, the terminal voltage of the generator changed too little, and frequency is stable during in this situation.

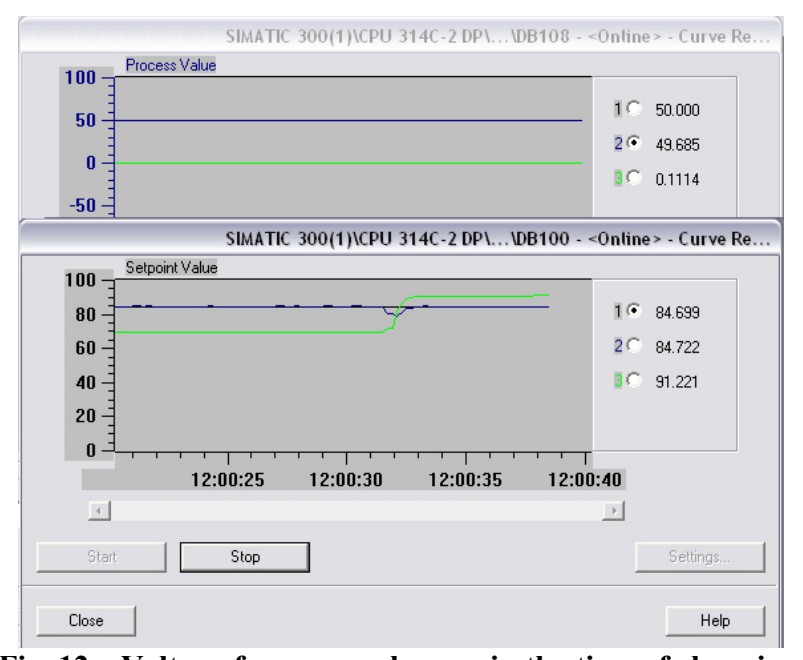

Fig. 12 Voltage-frequency changes in the time of changing excitation source PV to FC.

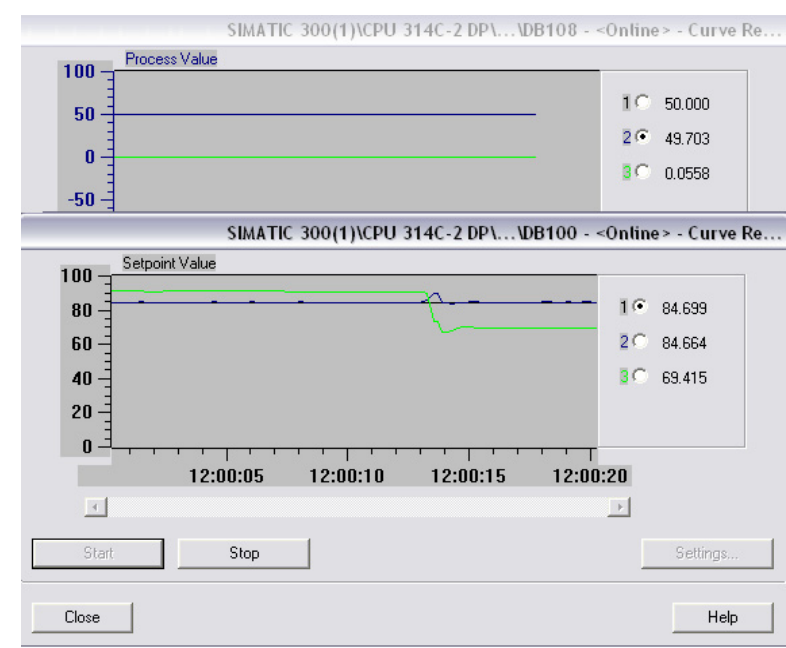

Fig. 13 Voltage-frequency changes in the time of changing excitation source FC to $\mathrm{PV}$. 
Figs. 12 and 13 show the proper energy source selection by the developed control card, respectively. The excitation energy source is selected as FC-based energy source from PV generator in Fig. 12. The solar energy source is also selected in Fig. 13 to provide a sustainable excitation current to the synchronous generator used in developed MHPP test system.

\section{Conclusions}

Today, the batteries have been used as the main excitation source in MHPPs, even they have many disadvantages to other excitation methods. The batteries have been charged in continuous operation. The charging condition has been obtained with a rectifier which using generated $\mathrm{AC}$ power.

The goal of this study is using two different type renewable energy sources for excitation of synchronous generator and developing a structure of the excitation current control. In the proposed method, there is not a battery system for the excitation, and the excitation also depends on a hybrid renewable energy system that consists of a PV system and a fuel cell system. These renewable energy sources supply the DC voltage directly, so the proposed system does not require a conversion system. The proposed method provides an easy and sustainable voltage control. The proposed method is also independent of the weather conditions.

In the study, a developed MHPP test system in the laboratory is presented and new hybrid renewable energy based DC excitation system for synchronous generator in this developed MHPP system is introduced. The proposed hybrid DC excitation system consists of a PV generator and an FC stack. The hybrid system is used for the excitation of the synchronous generator in developing MHPP test system, and it is used as a secondary energy source to provide the excitation current of the synchronous generator. Renewables generate DC power to supply the required excitation current, so this condition increases the overall efficiency of the system.

\section{References}

[1] Minott, D., and Delisser, R. 1983. "Cost Reduction Considerations in Small Hydropower Development." In Third Workshop on Small Hydropower, Vienna: United Nations Industrial Development Organization, 1-15.

[2] IEEE Std. 2006. "421.5-2005 IEEE Recommended Practice for Excitation System Models for Power System Stability Studies." In IEEE Std 421. 5-2005 (Revision of IEEE Std 421.5-1992), New York: IEEE, 0_1-85.

[3] Sisworahardjo, N. S., El-Sharkh, M. Y., and Alamb, M. S. 2008. "Neural Network Controller for Microturbine Power Plants." Electric Power Systems Research 78 (8): 1378-84.

[4] Shu, F., Chengxiong, M., and Luonan, C. 2006. "Optimal Coordinated Pet and Generator Excitation Control for Power Systems." International Journal of Electrical Power and Energy Systems 28 (3): 158-65.

[5] Brogan, W. L. 1991. Modern Control Theory. New Jersey, USA: Prentice Hall.

[6] Campero-Littlewood, E., Espinosa-Perez, G., and Escarela-Perez, R. 2006. "Transient Analysis of a Synchronous Generator Using a High-Order State Space Representation." In Proceedings of the IEEE Electronics, Robotics, and Automotive Mechanics Conference, 2: 258-63.

[7] Reichmeider, P. P., Querrey, D., Gross, C. A., Novosel, D., and Salon, S. 2000. "Internal Faults in Synchronous Machines II. Model Performance.” IEEE Transactions on Energy Conversion 15 (4): 380-3.

[8] McArdle, M. G., Morrow, D. J., Calvert, P. A. J., and Cadel, O. 2000. "A Fuzzy Tuning PID Automatic Voltage Regulator for Small Salient Pole Alternators." In Proceedings of the Power System Technology PowerCon 2000, 1: 103-8.

[9] Mora, E. S., Olivares, T. A., Vega, D. R., and Salinas, D. A. 2002. "The Effect of Induction Generators on the Transient Stability of a Laboratory Electric Power System." Electric Power Systems Research 61 (3): 211-9.

[10] Guney, K. R. I., and Onat, N. 2011. "Experimental Analysis of an Alternator, Excited with Photovoltaic Cells for Small Power Plants." Turkish Journal of Electrical Engineering and Computer Sciences 19 (3): 349-61.

[11] Ozturk, D. 2003. "Automatic Control with PLC in the Small Hydroelectric Power Plant." MSc thesis. Firat University.

[12] Ehnberg, S. G. J. 2005. "Reliability of a Small Power System Using Solar Power and Hydro." Electric Power System Research 74 (1): 119-27.

[13] Muhida, R., Mostovan, A., Sujatmiko, W., Park, M., and Matsuura, K. 2001. "The 10 Years Operation of a PV-Micro-Hydro Hybrid System in Taratak Indonesia." 
Solar Energy Materials \& Solar Cells 67 (1-4): 621-7.

[14] Bayrak, G., and Cebeci, M., 2014. "Grid Connected Fuel Cell and PV Hybrid Power Generating System Design with Matlab Simulink." International Journal of Hydrogen Energy 39 (16): 8803-12.

[15] Bayrak, G., and Cebeci, M. 2013. "A Novel Labview Based Anti-Islanding Detection Method for Grid-Connected PV Systems." In Proceedings of the International Conference on Renewable Energy Research and Applications ICRERA, 549-54.

[16] Bayrak, G. 2015. "A Remote Islanding Detection and Control Strategy for Photovoltaic-Based Distributed Generation Systems." Energy Conversion and Management 96 (May): 228-41.

[17] Bayrak, G., and Cebeci, M. 2013. "Monitoring a Grid Connected Photovoltaic Power Generation System with Labview." In Proceedings of the International Conference on Renewable Energy Research and Applications (ICRERA), 562-7.

[18] Bayrak, G., and Cebeci, M. 2014. “A Communication Based Islanding Detection Method for Photovoltaic Distributed Generation Systems." International Journal of $\begin{array}{lll}\text { Photoenergy } & 2014 \quad \text { (July): }\end{array}$ doi:10.1155/2014/272497.

[19] Ozdemir, M. T., Bayrak, G., Ural, Z., Gencoglu, M. T., and Cebeci, M. 2013. "Implementation of Synchronous
Generator Excited by Photovoltaic Cell/Fuel Cell for Micro Hydro Power Plants." Presented at the 4th Hydrogen Energy Conference, Hyfusen, Córdoba, Argentina.

[20] Bayrak, G., and Cebeci, M., 2014. "A Novel Anti-Islanding Detection Method for Grid-Connected Fuel Cell Power Generation Systems." International Journal of Hydrogen Energy 39 (16): 8872-80.

[21] Ozdemir, M. T., Sonmez, M., and Akbal, A. 2014. "Development of FPGA-Based Power Flow Monitoring System in a Microgrid." International Journal of Hydrogen Energy 39 (16): 8596-603.

[22] Ozdemir, M. T., and Orhan, A., 2012. "An Experimental System for Electrical and Mechanical Education: Micro Hydro Power Plant Prototype." Procedia-Social and Behavioral Journal 47 (August): 2114-9.

[23] Sathiyanarayanan, J. S., and Senthil Kumar, A. 2014. "Doubly Fed Induction Generator Wind Turbines with Fuzzy Controller: A Survey." The Scientific World Journal 2014 (June): 1-8. doi:10.1155/2014/252645.

[24] Nahidul Hoque, S., Bin Ahmad, N., Imtiaz Ahmed, C., and Zahari Bin, T. 2014. "Modeling, Control, and Simulation of Battery Storage Photovoltaic-Wave Energy Hybrid Renewable Power Generation Systems for Island Electrification in Malaysia." The Scientific World Journal 2014 (April): 1-21. doi:10.1155/2014/436376. 